1 Persson CGA. On the medical history of xanthines and other remedies for asthma. Thorax 1985;40:881-6.

2 Bogaert MG. Non linear kinetics of theophylline. Eur $\mathcal{f}$ Respir Dis 1984;65:1-3.

3 Woodcock AA, Johnson MA, Geddes DM. Theophylline prescribing, serum concentration and toxicity. Lancet 1983;ii:610-2.

4 William SJ, Parrish RW, Seaton A. Comparison of intravenous aminophylline and salbutamol in severe asthma. venous aminophyllin

5 Rossing TH, Fanta CH, Goldstein DH, Snapper JR, McFadden ER. Emergency treatment of asthma: comparison of acute effects of parenteral and inhaled sympathomimetics and infused aminophylline. Am Rev Respir Dis mimetics and infused

6 Rossing TH, Fanta CH, McFadden ER. A controlled trial of use of single versus combined drug therapy in the treatment of acute episodes of asthma. Am Rev Respir Dis 1981;123:190-4.

7 Siegel D, Sheppard D, Gelb A, Weinberg PF. Aminophylline increases the toxicity but not the efficacy of an inhaled $\beta$-adrenergic agonist in the treatment of acute exacerbations of asthma Am Rev Respir Dis 1985;132.283-6.

8 Littenberg B. Aminophylline treatment in severe acute asthma. A meta-analysis. $\mathcal{F} A M A$ 1988;259:1678-84.

9 Kelly HW, Menendez R, Volyes W. Lack of significant arrhythmogenicity from chronic theophylline and $\beta_{2}$ arrhythmogenicity from chronic theophylline and $\beta_{2}-$ adrenergic-combination thera
Ann Allergy 1985;54:405-10.

10 Sessler CN, Cohen MD. Cardiac arrhythmias during theophylline toxicity: a prospective continuous electrocardiographic study. Chest 1990;98:672-8.

\title{
Breathless on Everest - II
}

Everest is not climbed in the normal sense of climbing a mountain; you must lay siege to it. This means setting up camps at several levels. Apart from base camp there is usually a Camp 1 just above the icefall at 19000 feet and then an advanced base camp, or Camp 2, at the head of the Western Cym at 23000 feet. Camp 3 is based half way up the Lhotse face at 24500 feet and Camp 4 on the South Col at 26000 feet. On the South Col you look down into Tibet or Nepal and seem to be looking out over the whole of the rest of the world. The summit of Everest lies just above you and seems tantalisingly close.

I promised myself that I would cross the icefall and try to make some measurements at advanced base camp. I made measurements of spirometry, alveolar oxygen concentration, and arterial oxygen saturation at Camp 2 and was quite pleased with the data obtained, but then heard that because two of the climbers were incapacitated, one with altitude sickness and the other with a recurring back injury, I was to be added to the climbing team. This meant that I could have a crack at the summit. It was with terrible apprehension that I left Camp 2 on 5 May 1993, heading up this most frightening mountain. We made Camp 3 quite well without oxygen and, despite being very breathless, managed to get there in good time. We settled into our tents for the rest of the day to try to get some sleep before leaving early the following morning for Camp 4 on the South Col. I was very demoralised when the first assault team joined us back at Camp 3. They had left 24 hours earlier but had been forced back by the weather before the Geneva Spur. For me, the most inexperienced member of the team, the fact that Britain's best Himalayan climbers were turning round and coming back wrecked my rather fragile courage. The next day, however, our climbing leader John Barry decided we should give it a crack.

The sun was out and the winds were moderate but the hypoxia was terrible. We were now using oxygen at $2-31 / \mathrm{min}$, but even so could only manage three or four steps and then had to take 20 breaths. I now know what it feels like to have end stage emphysema. It seems that anything you do - eating, talking, sitting down and standing up, or taking a single step - causes so much breathlessness that you think you are never going to make it. We eventually did make it, but climbing only 1500 feet up from Camp 3 to Camp 4 on the South Col took us eight hours. The view from there was breathtaking.

The conditions on the South Col were nothing like the pictures that appeared in the Sunday newspapers. There were certainly discarded oxygen bottles, there were even one or two bodies, but the image of a rubbish dump was completely misplaced. I was not, however, doing well myself. We took the oxygen off on the South Col and I quickly became disorientated and confused. I tried to lie down in the snow and go to sleep but luckily I was spotted by the other members of the team who got me into the tent, into my down gear and sleeping bag, and put me on oxygen at $3 \mathrm{l} / \mathrm{min}$. I slept fitfully but awoke the next morning feeling a great deal better. I even felt well enough to make some measurements. I measured alveolar $\mathrm{PO}_{2}$ and arterial saturation on each of the four of us on and off oxygen. The resting arterial oxygen saturations of the group were under $70 \%$ and, in my case, this did not improve much with oxygen. Clearly I was developing pulmonary oedema and had to get down which required help from a colleague to leave the South Col. I clipped onto the fixed ropes and stumbled and fell most of the 3000 feet back to the safety of Camp 2. After two days of recuperation there we descended to base camp. Two days later I found myself escorting Harry Taylor, another member of our team, back to Britain. He had made the second British oxygenless ascent of Everest, but he had suffered the terrible consequences of frostbite, snow blindness, and pulmonary oedema. We were lifted by helicopter from base camp to Kathmandu and within 24 hours I was back in Glasgow. My overwhelming sensation was of relief that once again I could breathe normally.

ANDREW J PEACOCK 